\title{
ЛІНГВОСТИЛІСТИЧНІ ОСОБЛИВОСТІ МОВНИХ ПОРТРЕТІВ У ПРОЗІ ВАСИЛЯ СЛАПЧУКА
}

\author{
Олена ШТОНь
}

кандидат філологічних наук, доцент, Тернопільський національний педагогічний університет імені Володимира Гнатюка (УКРАЇНА)

e-mail: shtonolena@gmail.com

UDC 81'27: [81'38+81'42]:821.161.2'06-3.09(092)

https://orcid.org/0000-0002-4830-8210

DOI 10.25128/2304-1222.20.50.10

\begin{abstract}
The article deals with linguistic and stylistic features of verbal portraits in Vasyl Slapchuk's prose based on the novels "Wild Flowers", "Autumn in the Cheek", "Blind Rain", "Between the Worlds and Shining of the Lights, and the narratives "Cage for the Sky" and "Woman from Snow". We have found out that a reader gets the conception of characters' appearance, the peculiarities of the characters' tempers, their sensual spheres, their speeches, motions, physical or psychological states by means of Vasyl Slapchuk's verbal descriptions. Hence, writer's verbal portraits are a means of figurative specification and individualization as well as a means of expression of the author's attitude to his portraying. It has been established that depending on the number of characters described in the visual portraits and gender characteristics, a single female portrait sort predominates in Vasil Slipchuk's prose. Linguistic means of description in physical portraits (somatism and clothing) and psychological ones (kinetic vocabulary) are distinguished. Lexemes denoting parts of the body (somatisms) are present in all types of verbal portraits and are represented by nouns referring to the items of the human body and its parts (structural - head, face, eyes, nose, lips, hands, feet, structurally separating - moustache, beard, bristle, bald spot, braids, breast, waist and structural characteristics - mug, muzzle, peepers), clothing and kinetic vocabulary. We have defined that specification and individualization of characters in verbal portraits are carried out by means of imagery, and comparison, epithet and metaphor are the most expressive ones.
\end{abstract}

Key words: verbal portrait, typology of verbal portraits, linguistic means of portraying, somatism, clothing, comparison, epithet, metaphor.

У статті описано лінгвостилістичні особливості мовних портретів у прозі Василя Слапчука, зокрема у романах «Дикі квіти», «Осінь за щокою», «Сліпий дощ», «Поміж світів і сяяння світил» та повістях «Клітка для неба» і «Жінка зі снігу». 3'ясовано, що мовні портрети у творах письменника перш за все створюють у читача уявлення про зовнішність персонажів, особливості їх характеру, почуттєвої сфери, мовлення, рухів, фізичного чи психологічного стану, є засобом образної конкретизації та індивідуалізації, а також засобом вираження авторського ставлення до описуваного. Виявлено: залежно від кількості описуваних персонажів у мовному портреті та гендерних характеристик, у прозових творах Василя Слапчука переважає одиничний жіночий портретний різновид. Виокремлено також мовні засоби портретування у фізичних портретах - соматизми та вестизми, у психологічних кінетичну лексику. Описано соматизми, які наявні у всіх типах мовних портретів і представлені іменниками на позначення тіла людини та його частин (структурні - голова, обличчя, очі, ніс, губи, руки, ноги, структурно-виокремлювальні - вуса, борода, щетина, лисина, коси, груди, талія і структурно-характеристичні - пика, морда, баньки), вестиальну та кінетичну лексику. Визначено, що конкретизація та індивідуалізація персонажів у мовних портретах здійснюється за допомогою засобів образності, найбільш виразними із яких є порівняння, епітет та метафора.

Ключові слова: мовний портрет, типологія мовних портретів, мовні засоби портретування, соматизм, вестизм, порівняння, епітет, метафора. 
Artykuł opisuje lingwostylistyczne cechy portretów językowych w prozie Wasyla Słapczuka, zwłaszcza w powieściach „Dzikie kwiaty”, „Jesień za policzkiem”, „Ślepy deszcz”, „Między światów i lśnienia słońc” oraz „Klatka dla nieba” i „Kobieta ze śniegu”. Stwierdzono, że portrety językowe w utworach pisarza przede wszystkim dają czytelnikowi wyobrażenie o wyglądzie zewnętrznym postaci, cechach ich charakteru, sfery uczuciowej, mowy, ruchów, stanu fizycznego lub psychicznego, są środkiem obrazowej konkretyzacji i indywidualizacji, a także środkiem wyrażenia stosunku autora do tego, co opisuje. Stwierdzono, że w zależności od liczby opisywanych postaci w portrecie językowym oraz charakterystyk genderowych, w utworach prozowych Wasyla Słapczuka dominuje rodzaj pojedynczego portretu kobiecego. Wyróżniono także językowe sposoby przedstawiania portretów fizycznych - somatyzmy i westyzmy, w portretach psychologicznych - słownictwo kinetyczne. Opisano somatyzmy, które występują we wszystkich rodzajach portretów językowych i są reprezentowane przez rzeczowniki oznaczające ludzkie ciało i jego części (strukturalne - glowa, twarz, oczy, nos, usta, dłonie, stopy; strukturalno-wyróżniające - wąsy, broda, zarost na twarzy, tysina, warkocze, klatka piersiowa, talia, i strukturalno-charakterystyczne - pysk, morda, gały), słownictwo powiązane z ubraniem oraz leksyka kinetyczna. Ustalono, że konkretyzacja i indywidualizacja postaci w portretach językowych odbywa się za pomocą środków stylistycznych, z których najbardziej wyraziste są porównania, epitety i metafory.

Slowa kluczowe: portret językowy, typologia portretów językowych, lingwistyczne sposoby portretowania, somatyzm, westytyzm, porównanie, epitet, metafora.

Постановка проблеми. Мова сучасної української художньої прози позначена дією активних лексико-семантичних процесів. Це запозичення, жаргонізація, детермінологізація, формування нових значень та різних семантичних конотацій. Характерним для неї є також активне проникнення у мовну тканину творів елементів розмовно-побутового мовлення та публіцистистики. Оскільки сучасна проза належить до літератури постмодернізму, то іiі визначальними рисами є іронічність, парадоксальність мовлення, активне використання алюзій тощо. Яскраво виявляються вони у творах Василя Слапчука, специфічною формою критичного та емоційного освоєння дійсності якого є іронія, що виражається не в глузуванні, а у легкій, доброзичливій насмішці. У сюжетно-композиційній побудові прозових творів митця значну роль відграють портретні характеристики, зумовлені жанровою та дискурсивною специфікою його текстів.

Аналіз останніх досліджень і публікацій. Аналізуючи поетичний i прозовий доробок Василя Слапчука, літературознавці [Бондар-Терещенко 2004; Мединська 2003; Оляндер 1999], відзначають притаманні його творчості витончений психологізм, делікатну іронію, парадоксальність, алюзійність, неоднозначність та багатоплановість філософських запитань, схильність до афористичних висловлювань та виразного метафоризму. Специфіку порівнянь в авторській мовній картині світу Василя Слапчука і мовні засоби вираження суб'єктивно-оцінної іронічної модальності у його прозі стали предметом аналізу у наших публікаціях [Штонь 2016; Штонь 2018].

Мовний портрет досліджували І. Білодід, С. Бибик, С. Срмоленко, Ф. Жилко, Г. Сюта, З. Шевчук та ін. Портретування у художньому тексті вивчали І. Бикова, Т. Іжевська, К. Кусько, Т. Насалевич, К. Писаренко, А. Скачков та ін. Проте специфіка індивідуально-авторської вербальної портретизації людини у творах українського 
письменника Василя Слапчука ще не була предметом окремих мовознавчих студій. Це й зумовлює актуальність теми наукової розвідки.

Мета статті: 3'ясувати лінгвостилістичні особливості мовних портретів у прозі Василя Слапчука. Джерелом дослідження слугували твори, що ввійшли до таких видань: Слапчук В. Сліпий дощ: роман. Київ: Факт, 2003. 336 с.; Слапчук В. Дикі квіти: роман. Київ: Факт, 2005. 296 с.; Слапчук В. Осінь за щокою: роман. Київ: Факт, 2005. 280 с.; Слапчук В. Клітка для неба: повісті. Київ: Факт, 2007. 280 с.; Слапчук В. Жінка зі снігу: повість. Київ: Факт, 2008. 278 с.; Слапчук В. Поміж світів і сяяння світил: роман. К.: Український пріоритет, 2016. 280 с. Посилання на ілюстративний матеріал, узятий із цих видань, подаватимемо скорочено в дужках. Реалізація поставленої мети зумовила використання таких методів та прийомів досліджень: описового, що передбачає відбір, систематизацію досліджуваного матеріалу, спостереження за мовними фактами, інтерпретацію та узагальнення; семантико-стилістичного 3 метою аналізу мовних одиниць із погляду їх змістового навантаження; зіставного (для порівняння засобів портретування у гендерних, фізичних, соціальних, психологічних мовних портретах), прийом кількісних підрахунків 3 метою встановлення частотності різних груп лексики та засобів виразності у мовних портретах.

Наукова новизна роботи полягає у з'ясуванні лінгвостилістичної специфіки мовновного портретування у прозових творах Василя Слапчука, іiі визначає також матеріал, який ще не був предметом окремого лігвостилістичного дослідження.

Виклад основного матеріалу. Як відомо, портрет у художньому творі виконує функції образної конкретизації та індивідуалізації зображуваних персонажів, а також є засобом розкриття їх характеру та почуттєвої сфери.

У досліджуваних романах та повістях серед виявлених портретів, залежно від кількості словесно-художніх образів людини у межах одного опису, переважає одиничний портретний різновид (крім одиничного, виділяють групові та колективні [Писаренко 2016:5], здвоєний, строєвий і груповий мовні портрети [Скачков 2007: 4]). Опишемо детальніше одиничні портрети у прозі митця, які проаналізуємо, спираючись на комплексну класифікацію мовних портретів, подану К. Писаренко у дисертації «Мовний портрет людини в історичній прозі Р. Іваничука (на матеріалах романного триптиха «Хресна проща»)» та в інших публікаціях: «За тематичним (змістовим) підходом основними типами мовних портретів у художніх текстах $\epsilon$ гендерний, фізичний, психологічний (характероцентричний), соціальний та мовленнєвий» [Писаренко 2016: 152]. У гендерному дослідниця виокремлює чоловічі і жіночі портрети, а в межах кожної групи - підгрупи за віком; у фізичному - соматичні (лексика, що стосується обличчя, статури тощо), вестиальні (назви одягу, аксесуарів, артефактів), рухові, мовленнєві [Писаренко 2016:152-154]. 
Зауважимо, що у художньому тексті усі типи комбінюються, адже описуючи жінку чи чоловіка (гендерний портрет), автор може акцентувати або на зовнішності (фізичний портрет), або на їх внутрішньому світі (психологічний портрет), або на соціальному статусі (соціальний портрет).

У прозі Василя Слапчука серед гендерних портретів майже вдвічі переважають жіночі. Ядерними лексемами у таких описах виступають: жінка, мати, тітка, молодиця, дівчина, юнка, дівчинка, баба. Мовні портрети, крім образної конкретизації та індивідуалізації персонажів, $\epsilon$ також засобом виявлення авторського ставлення до описуваного, яке у творах вербалізують слова із позитивним чи негативним значенням: «Серафіта перебирає тоненькими, майже прозорими пальчиками... дерев'яне намисто...» (Клітка, с. 73). «Була юнка вродливою й тендітною, такою тендітною й витонченою» (Сліпий, с. 13). Негативну оцінку у жіночих портретах персонажам надають просторічні та згрубілі слова: «Це огрядне бабисько на непропориійно тоненьких ніжках не визнавало компромісів» (Дикі, с. 38); «Я бачу там розтріпану, розпатлану жінку зі спотвореним непривабливим лицем. Один червоний, зашмарканий ніс чого вартий!» (Дикі, с. 282).

У чоловічих портретах, серед ядерних слів за гендерною ознакою у яких - чоловік, діd, хлопець, хлопчик, дядько, враження від зовнішності передає переважно негативно оцінні слова: «Цей дядько мені не подобався, він мав червоне лице, бородавку біля носа $і$ чорного нігтя...» (Клітка, с. 37); “Класичний мордатий мент із нахабними очима. I, судячи 3 поведінки, зі специифічним почуттям гумору» (Осінь, с. 126); «Чоловік мав видовжене трикутне обличчя з гострим довгим носом із горбинкою та гострим, загнутим уперед, підборіддм. На голову він собі напнув шкіряного шолома, в таких на початку ери авіа-та автомобілебудування розгулювали, точніше роз'їжджали пілоти й водії різних первісних засобів пересування. Бракувало тільки захисних окулярів. Одягнутий був у мишачого кольору френч часів першої світової війни (злиденна розкіш гуманітарки; обноски циивілізації на наших людях набувають дуже навіть стильного вигляду), поверх гудзиків прикріплені кружечки, витяті з консервної бляманки, на яких нашкрябані якісь знаки-ієрогліфи» (Сліпий, 252). Прихована іронія прочитується і в портреті хлопчика: «Тільки тепер помітив поряд із жінкою хлопчика років семи. Непропорційно велика голова, покрита ріденькими світлими кучериками, невідомо як трималася на тоненькій шийці. Вздовж тулуба теліпалися доволі довгі в'ялі мотузочки рук. Але найбільше вражали очі - зовсім не дитячі, якісь начебто й не людські, - очі гуманоӥда» (Осінь, с. 13).

Відступаючи від традиційного портретування дітей, залучаючи до творення образів непередбачувані асоціації, митець описує дівчаток: «Оленки я здалеку не впізнав. Видалася мені мініатюрною дорослою жінкою... на ній - розкішна голуба блискуча, із прорізом на все стегно, сукня. Завершували образ наквецяні помадою губи та підмальовані синім очі» 
(Клітка, с. 58); «...ні на вундеркінда, ні на акселератку вона не скидалася. Радше на мініатюрну копію жінки-зека (зеківки?) із сукупним двадиятирічним стажем відсиджування» (Сліпий, с. 245); «Важко клигаючи, загортаючи носаками цілі гори листя, наближалася Люська - дівчинка років п'яти. Гном у червоних черевиках...» (Сліпий, c. 240).

Вербалізація жіночих та чоловічих образів репрезентує мовну картину світу письменника, яка не завжди відповідає традиційним уявленням українців. Жінки постають впевненими, вольовими, агресивними, чоловіки ж - слабкими і безвольними: «Мати, мов камінчик у взутті, тисне, муляє, докучає...» (Сліпий, с. 126); «Вийшло ж навпаки - на мою голову звалилася вся чоловіча робота, і мати стояла наді мною, ніби німець з нагайкою» (Дикі, с. 37); «Баба вдає з себе інтелігентку... сама ж лається, як остання буфетниця» (Дикі, с. 115); «Виглядав тато неважнецьки. Наче равлик без мушлі - дивитись боляче» (Жінка, с. 107); «Тато замовк. Сидів на передньому сидінні, наче мокрий горобчик» (Жінка, c. 107).

У мовному портретуванні Василя Слапчука, залежно від співвідношення зовнішнього i внутрішнього, виокремлюємо фізичні і психологічні портрети. У фізичних деталі зовнішності й одягу дають виключно зорове уявлення про зовнішність персонажів: «B Ірияі золоте волосся. Кучеряве й пухнасте. Не голова, а велика м'яка куля. Волосся в Іриі завжди таке» (Дикі, с. 127); «Та й про свого сусіду за столом тільки й міг сказати, щзо в нього волосся зібране на потилиці в кінський хвіст, а над чолом беруться залисини» (Осінь, с. 162). Психологічні портрети слугують засобом передачі внутрішньої сутності персонажів (рис характеру та емоційного стану): «Зоя всміхнулася самими вустами. Очі від спогаду про ту давню зиму взялися кригою» (Осінь, с. 124); «Це вперше очі жжінки спалахнули злістю, вона ховала цฺю злість у собі, як кішка в м'якій, пухнастій лапі ховає кігті» (Сліпий, с. 314).

Серед мовних одиниць на позначення візуального образу у прозі Василя Слапчука активно функціонує соматична лексика (вона складає приблизно дві третини від усіх зафіксованих мовних фактів, що належать до інших груп). Кінетична і вестиальна відповідно становлять одну третину і у відсотковому співвідношенні є рівноцінними.

Мовні засоби портретування у фізичних описах - соматизми та вестизми, у психологічному важливою $є$ кінетична лексика. Оскільки соматизми наявні у всіх типах мовних портретів, тому зрозуміло, що ця група лексики є найчастотнішою. Соматизми представлені іменниками, які позначають тіло людини та його частини. Серед них, залежно від функціонального навантаження, виділяють структурні (голова, обличчя, очі, ніс, губи тощо), структурно-виокремлювальні (вуса, борода, щетина, лисина, коси, перса) i структурно-характеристичні соматизми (пика, морда, баньки). 
У творах митця ознаки зовнішності називають такі структурні соматизми:

- очі; «Зблизька ї̈ видає лище, навіть не лице, а очі. Великі й тужні, сповнені якогось столітнього досвіду» (Осінь, с. 110); «Класичний мордатий мент із нахабними очима» (Осінь, с. 126); «Кладу куртку на вішак, ... зустрічаю там блідого типа з пригаслими очима...» (Жінка, с. 174);

- обличчя (лице): «Лице у матері гарне, якщз не прискіпуватися, то й вродливе, а як причепуриться - з такою дружиною не соромно, навіть приємно на люди вийти» (Сліпий, с. 41); «Він припалив. Красиве, вольове обличчя. Кількаденна щеетина робила його лице суворим, навіть грізним» (Клітка, с. 69);

- ніс: «Кирпатий носик надавав обличчю веселого і трохи задерикуватого виразу...» (Сліпий, с. 35); «Розу не назвеш потворною, однак трохи великуватий ніс спільно з вічно суворими рисами обличчя роблять ї̈ непривабливою для чоловіків...» (Дикі, с. 201);

- зуби: «Проводив дівчат поглядом. У вродливої-зуби криві, рідкі, і дірок у них, мабуть, не менше, як на сімнадиять пломб...» (Сліпий, с. 230); «У неї красиві рівні зуби. Гарні зуби тепер рідкість. Цікаво, від природи у неї такий вищир чи завдяки стоматологу?» (Клітка, с. 96);

- вії: «Вї̈ в Коли довгі й лапаті. Такі вї я бачив лише у маленьких дівчаток» (Осінь, с. 76); «Роза із зусиллям ковтає слину, часто моргає - эї чорні вї, вони у неї від природи довгі, густі, загнуті на кінчиках...» (Дикі, с. 207).

Структурно-виокремлювальні трапляються у мовній тканині прозових творів Василя Слапчука рідше, ніж структурні. Серед них такі: «Він припалив. Красиве, вольове обличчя. Кількаденна щцетина робила його лище суворим, навіть грізним» (Клітка, с. 69); «У неї світле нефарбоване (майже блондинка) волосся й чорні (не щуипані) брови. Великі груди й маленька долонька. Усміхнені вуста й сумні очі» (Осінь, с. 104).

Частотними у фізичному, а особливо, у соціальному портретуванні, $є$ вестизми іменники, що називають одяг та аксесуари: «..біля воріт найближчої хати стоїть повновида молодиия. У легкому (рукав до ліктя) із глибоким вирізом на грудях домашньому халаті. Світле (майже блондинка) волосся зібране на потилищі у вузол» (Сліпий, с. 259); «На жінці - шкіряна коричнева куртка, довга пряма спідниця, голова пов'язана яскравою квітчастою хустиною. На буряки так не вдягаються» (Сліпий, с. 258); «На ній - бірюзовий брючний костюм. Туфельки на високих підборах, ридикюль, не кажучи вже про кліпси й камінь у каблучці...» (Жінка, с. 49).

Кінетичні лексеми, які позначають міміку, жести, переважають у психологічних портретах: «Уловивщи його порух, огрядна молодиия звабливо зблиснула золотою коронкою» (Клітка, с. 241); «Ця подивовано вилупила очі, ї̈ руді брови стрибнули на маківку» (Клітка, с. 228). 
Конкретизація та індивідуалізація персонажів у мовних портретах здійснюється за допомогою засобів образності, найбільш виразними із яких є порівняння, епітет та метафора. Найчастіше для створення живих, переконливих, іноді несподіваних образів, автор використовує порівняння: «Лідія гасить цигарку у попільничці з таким завзяттям, наче товче носом збитошного кота, котрий напаскудив у непризначеному для изього місціџ (Поміж світів, с. 29); «Чоловік з ріденькою, як парк 900-річчя Луцька, дяківською борідкою сидів на моріжку у позі лотоса ...» (Клітка, с. 273). Саме у порівняннях яскраво виявляється суб’єктивно-оцінна іронічна модальність прози Василя Слапчука: чим більшою $\epsilon$ невідповідність між ознаками порівнюваних об'єктів, їх полярність у семантичному i стилістичному планах, тим більше іронії в самому порівнянні [Штонь 2018: 266]. Наприклад: «Своєю зовнішністю цьоця Офелія нагадувала японського самурая (після виходу на пенсію), якими їх традииійно зображають художники. Така ж зачіска, такі ж вузькі очі та роздуті щзоки... Лице в тьоті Офелії прикрашали чорні вуса (навіть трохи густіші, ніжс в Анатолія перед військом) $\boldsymbol{i}$ кілька кущиків бороди» (Сліпий, с. 236), «А зустрічати однаково прийдеться, - Ця проявляла мяку, наче хокейна шайба, невблаганність» (Клітка, с. 272); «Дідове обличчя нагадувало зморщеного, покритого сивою курявою кактуса» (Сліпий, с. 200); «А щ̧е - він чорний, як солдатський чобіт. Значно чорніший від Майкла Джексона, але трохи світліший, ніжс Майк Тайсон» (Дикі, 176).

Епітети, вжиті письменником у мовних портретах, використовуються переважно у складі структурно-виокремлювальних соматизмів для позначення кольору і відтінків очей, шкіри, волосся: «золотавий пушок на шийці» (Жінка, с. 33); «каштанові очі» (Дикі, с. 225); «молочно-біла шкіра» (Жінка, с. 33); «солом'яні кучерики» (Клітка, с. 5); «сиве волосся» (Сліпий, с. 239), або ж на позначення розміру та інших особливостей зовнішності, як-от: «короткі й жорсткі вуса» (Дикі, с. 225); «лице у нього доволі пом'яте» (Жінка, с. 234).

Метафор у портретних описах небагато: «Очі від спогаду про ту давню зиму взялися

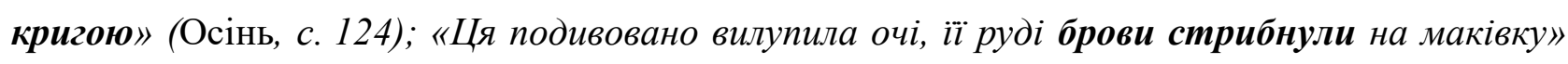
(Клітка, с. 228); «Серафіта дивиться на мене з-під бриля буритиновими очима косуленятка» (Клітка, с. 72).

У портретних описах митець вдається також до антитези: «У неї світле нефарбоване (майже блондинка) волосся й чорні (не щииані) брови. Великі груди й маленька долонька. Усміхнені вуста й сумні очі» (Осінь, с. 104). «Його очі - два полюси, Арктика й Антарктида. І жодного криголома поблизу» (Осінь, 10).

Висновки. Мовні портрети у прозі Василя Слапчука не лише створюють у читача уявлення про зовнішність персонажа, особливості його мовлення, рухів, фізичного чи психологічного стану, вони передусім $є$ засобом репрезентації ставлення автора до описуваного. Залежно від кількості описуваних персонажів у мовному портреті та гендерних 
характеристик у досліджуваних творах переважає одиничний жіночий портретний різновид.

Ядерними лексемами у таких описах виступають: жінка, мати, тітка, молодиця, дівчина, юнка, дівчинка, баба. У чоловічих мовних портретах- ядерні лексеми за гендерною ознакою - чоловік, дід, хлопець, хлопчик, дядько.

Фізичні, соціальні і психологічні мовні портрети репрезентують переважно соматизми, які є найбільш частотними, адже вони наявні у всіх типах мовних портретів, а також вестизми та кінетична лексика. Серед соматизмів, представлених іменниками на позначення тіла людини та його частини, залежно від функціонального навантаження у прозі Василя Слапчука переважають структурні (голова, обличчя, очі, ніс, губи тощо); структурно-виокремлювальні (вуса, борода, щетина, лисина, коси, перса) та структурнохарактеристичні (пика, морда, баньки) функціонують рідше. У фізичному, а особливо у соціальному портретуванні, частотними також є вестизми - іменники, що називають одяг та аксесуари. Кінетичні лексеми, які позначають міміку, жести, більш уживаними є в психологічних портретах. Основними виражальними засобами у портретних описах митця виступають порівняння, епітети та метафори. Перспективи подалыших розвідок полягають у дослідженні специфіки мовних портретів у творах інших сучасних письменників.

\section{ЛITEPATУРA}

Бондар-Терещенко, I. (2004), Від пафосу до скепсису: реконструкція сакрального в поезії Василя Слапчука, Слово i час. № 7. 48-51 [Bondar-Tereshchenko, I. (2004), Vid pafosu do skepsisu: rekonstruktsiya sakral'noho v poeziyi Vasilya Slapchuka, Слово $i$ час. No 7. 48-51].

Мединська, А. (2003), Національно-культурний аспект підтексту поезій Василя Слапчука. Філологічні студіï: наук. часопис. Луцьк. № 2. 109-122 [Medins'ka, A. (2003), Natsional'no-kul'turniy aspekt pidtekstu poeziy Vasilya Slapchuka. Філологічні студіï. Lutsk. No 2. 109-122].

Оляндер, Л. К. (1999), Про творчість Василя Слапчука. «Роде наш красний...». Волинь у долях краян $i$ людських документах. Луцьк. T.3. 197-209 [Olander, L. K. (1999), Pro tvorchist' Vasilya Slapchuka. «Rode nash krasniy...». Волинь у долях краян і людських документах. Lutsk. T.3. 197-209].

Писаренко, К.В. (2016), Типологія мовних портретів персонажів у художніх текстах триптиху «Хресна проща» Р. Іваничука: змістовий аспект. Лінгвістичні дослідження: збірник наукових праць ХНПУ ім. Г. С. Сковороди. Харків, Вип. 42. 150-155 [Pisarenko, K. V. (2016), Tipolohiya movnikh portretiv personazhiv u khudozhnikh tekstakh triptikhu «Khresna proshcha» R. Ivanicchuka: zmistoviy aspekt. Linhvistichni doslidzhennya: zbirnik naukovikh prats' KhNPU im. H. S. Skovorodi. Kharkiv. Vip. 42. 150-155].

Скачков, А. Ю. (2007), Лінгвостилістичні особливості портретних описів у творах М. Коцюбинського: автореф. дис. ... канд. філол. наук. Харків [Skachkov, A. Yu. (2007), Linhvostilistichni osoblivosti portretnikh opisiv u tvorakh M. Kotsyubins'koho: avtoref. dis. ... kand. filol. nauk. Charkiv].

Штонь, О. П. (2016), Порівняння в авторській мовній картині світу Василя Слапчука. Наукові записки ТНПУ. Серія: Мовознавство. Вип. I (25). 118-123 [Shton', О. Р. (2016), Porivnyannya v avtors'kiy movniy kartini svitu Vasilya Slapchuka. Naukovi zapiski TNPU. Серія: Мовознавство. Vip. I (25). $118-$ 123].

Штонь, О. П. (2018), Мовні засоби вираження суб'єктивно-іронічної модальності у прозі Василя Слапчука. Лінгвістичні дослідження: збірник наукових праць ХНПУ ім. Г. С. Сковороди. Харків. Вип. 48. 264-269 [Shton', О. Р. (2018), Movni zasobi virazhennya subyektivno-ironichnoyi modal'nosti u prozi Vasilya Slapchuka. Linhvistichni doslidzhennya: zbirnik naukovikh prats' KhNPU iм. H. S. Skovorodi. Kharkiv. Vip. 48. 264-269]. 